DOI: https://doi.org/10.24127/ajpm.v10i1.3384

\title{
ANALISIS KEMAMPUAN LITERASI MATEMATIKA SISWA BERDASARKAN MULTIPLE INTELLIGENCE DALAM MENYELESAIKAN SOAL MATEMATIKA
}

\author{
Irmawaty Natsir ${ }^{*}$, Anis Munfarikhatin ${ }^{2}$ \\ $1^{1 * 2}$ Universitas Musamus, Merauke, Indonesia \\ ${ }^{*}$ Corresponding author. \\ E-mail: $\quad$ natsir_fkip@unmus.ac.id ${ }^{1 *}$ \\ munfarikhatin_fkip@unmus.ac.id ${ }^{2)}$ \\ Received 11 December 2020; Received in revised form 06 March 2021; Accepted 05 April 2021
}

\begin{abstract}
Abstrak
Penelitian ini bertujuan mendeskripsikan kemampuan literasi matematika siswa berdasarkan kecerdasan majemuk (multiple intelligence) dalam menyelesaikan soal matematika pada konten change and relationship dan space and shape. Penelitian ini merupakan penelitian deskriptif kualitatif. Instrumen yang digunakan dalam penelitian ini adalah angket kecerdasan majemuk (multipel intelligence), tes kemampuan literasi matematika dan pedoman wawancara. Subjek dalam penelitian ini adalah empat orang siswa yang dipilih berdasarkan kecerdasan dominan dari seluruh siswa kelas VIII SMP IT Ibnu Sina dan mewakili setiap kecerdasan yaitu kecerdasan intrapersonal, interpersonal, kinestetik, dan logika matematika. Hasil penelitian menunjukkan bahwa: 1) subjek dengan kecerdasan intrapersonal hanya memenuhi indikator kemampuan komunikasi pada konten change and relationship dan space and shape; 2) subjek dengan kecerdasan interpersonal hanya mampu memenuhi indikator kemampuan matematisasi pada konten change and relationship dan pada konten space and shape subjek belum memenuhi indikator kemampuan komunikasi, matematisasi, dan kemampuan memilih strategi; 3) subjek dengan kecerdasan kinestetik belum memenuhi indikator kemampuan komunikasi, matematisasi, dan memilih strategi untuk menyelesaikan masalah pada konten change and relationship maupun space and shape; 4) subjek dengan kecerdasan logika matematika telah memenuhi indikator kemampuan komunikasi, matematisasi, dan memilih strategi dalam menyelesaikan masalah pada konten change and relationship.
\end{abstract}

Kata kunci: Literasi matematika; multiple intelligence; change and relationship; space and shape.

\begin{abstract}
This study aims to describe students' mathematical literacy skills based on multiple intelligence in solving math problems on the content of change and relationship and space and shape. This research is a qualitative descriptive study. The instruments used in this study were multiple intelligence questionnaires, math literacy skills tests and interview guides. The subjects in this study were four students who were selected based on the dominant intelligence of all eighth grade students of SMP IT Ibnu Sina and represented each intelligence, namely intrapersonal, interpersonal, kinesthetic, and mathematical logic. The results showed that: 1) subjects with intrapersonal intelligence only met the indicators of communication skills in content change and relationship and space and shape; 2) the subject with interpersonal intelligence is only able to meet the indicators of mathematical ability in change and relationship content and the subject's space and shape content has not met the indicators of communication skills, mathematics and the ability to choose strategies; 3) subjects with kinesthetic intelligence have not met the indicators of communication skills, mathematics, and choose strategies to solve problems in change and relationship content as well as space and shape; 4) the subject with mathematical logic intelligence has met the indicators of communication skills, mathematics, and chooses strategies in solving problems with content change and relationship.
\end{abstract}

Keywords: mathematical literacy; multiple Intelligence; change and relationship; space and shape

This is an open access article under the Creative Commons Attribution 4.0 International License 
DOI: https://doi.org/10.24127/ajpm.v10i1.3384

\section{PENDAHULUAN}

$\begin{array}{lcr}\text { Literasi } & \text { matematika } & \text { merupakan } \\ \text { kemampuan } & \text { individu } & \text { dalam } \\ \text { menggunakan } & \text { metode yang efisien }\end{array}$ untuk memecahkan masalah, melakukan penilaian terhadap apa yang dikerjakan, menganalisis situasi dan menarik kesimpulan (Genc \& Erbas, 2019). OECD (2013) dan Stecy (2011) mengemukakan hal serupa bahwa literasi matematika adalah kemampuan seseorang dalam merumuskan, menerapkan dan menafsirkan matematika dalam berbagai konteks sehingga dapat membantu seseorang dalam mengenal peran dan manfaat matematika di kehidupan nyata. Kemampuan literasi matematika meliputi penalaran matematika, penggunaan konsep, prosedur, fakta dan alat matematika untuk mendeskripsikan, menjelaskan, dan memprediksi fenomena (OECD, 2019).

Terdapat empat konten dalam menilai kemampuan literasi matematika yang digunakan dalam Programme for International Student Assesment (PISA) meliputi: (1) Ruang dan bentuk (space and shape) berkaitan dengan materi geometri; (2) Perubahan dan hubungan (change and relationship) berkaitan dengan materi aljabar (3) Bilangan (Quantity) berkaitan dengan hubungan bilangan dan pola bilangan (4) probabilitas/ ketidakpastian (Uncertainly) berkaitan dengan statistika dan peluang (Johar, 2012).

Survei yang dilakukan oleh Programme for International Student Assesment (PISA) untuk mengukur kemampuan anak usia 14-15 tahun menunjukkan hasil literasi matematika siswa di Indonesia belum menunjukkan prestasi yang memuaskan hal ini terlihat adanya penurunan skor yang diperoleh siswa di tahun 2018 sebesar 379 jika dibandingkan pada tahun 2015 sebesar
386. Lemahnya kemampuan literasi matematika siswa di Indonesia dikarenakan soal-soal yang diajarkan di sekolah kurang memberikan keterampilan pemecahan masalah yang membutuhkan pemikiran logis, siswa di Indonesia terbiasa dengan penyelesaian soal menggunakan jawaban yang teoritis dan prosedural (Aini, R.N, dkk, 2018). Hal tersebut sejalan dengan fakta di lapangan dimana kemampuan siswa SMP IT Ibnu Sina masih kurang dalam menemukan strategi menyelesaikan masalah, proses pembelajaran di kelas lebih ditekankan pada hasil bukan pada proses, dan soal-soal yang diberikan sebagian besar belum dikaitkan dengan permasalahan kontekstual sehingga siswa belum menerapkan ilmu matematika sebagai alat bantu dalam penyelesaiannya. Dimana dalam proses pembelajaran matematika, siswa dituntut tidak hanya memiliki kemampuan berhitung saja, melainkan juga memiliki kemampuan bernalar yang logis dalam menyelesaikam masalah. Permasalahan dalam matematika tidak semata-mata masalah yang berupa soal rutin akan tetapi lebih kepada permasalahan yang dihadapi sehari-hari (Sari, 2015).

Hasil penelitian Munfarikhatin, A dan Natsir, I (2020) tentang kemampuan literasi matematika siswa kelas VIII SMP Negeri 1 Winong menunjukkan $80 \%$ siswa berada pada level di bawah 1 dan $20 \%$ berada pada level 1. Hasil penelitian ini sejalan dengan hasil tes PISA dimana sebagian besar siswa berada pada level 1. Namun, terdapat perbedaan antara hasil penelitian Widodo, dkk dengan hasil penelitian Munfarikhatin, A dan Natsir, I. Dalam penelitian Widodo, S. A, dkk (2015) level literasi matematis siswa kelas XIA-4 SMA Negeri 01 Ambulu diperoleh hasil $8,57 \%$ siswa berada 
pada level 2, 60\% siswa berada pada level 3,20\% siswa berada pada level 4, dan $11,43 \%$ siswa berada pada level 5 . Lebih lanjut, hasil penelitian Astuti, N.K., dkk (2018) tentang kemampuan literasi matematika siswa kelas VIII SMP Swasta di Kota Kendari berada dalam kategori sangat rendah, dimana rerata perolehan nilai siswa dari delapan sekolah hanya mencapai 19,87 dan umumnya kemampuan literasi matematika siswa berada pada level 2 . Dari beberapa hasil penelitian tersebut menunjukkan bahwa adanya perbedaan capaian literasi matematika siswa di Indonesia yang sangat dipengaruhi oleh beberapa faktor diantaranya faktor personal, faktor intruksional dan faktor lingkungan (Syawahid, M., \& Putrawangsa, S, 2017).

Faktor personal menjadi salah satu faktor yang memengaruhi capaian lietarsi matematika yang meliputi kecerdasan, persepsi dan kepercayaan diri siswa. Namun, dalam penelitian ini faktor personal yang diteliti adalah kecerdasan. Setiap siswa memiliki kecerdasan yang berbeda, ada siswa cerdas di bidang bahasa, matematika, adapula siswa yang cerdas di bidang seni ataupun bidang lainnya. Kecerdasan yang dimiliki siswa tidak hanya ditentukan dari nilai yang dicapai, potensi maupun sifat bawaan yang dimilikinya melainkan ditentukan pula dari kemampuan siswa dalam menghadapi dan memecahkan suatu masalah. Kecerdasan siswa yang berbeda-beda dikenal dengan kecerdasan majemuk (multiple intelligence). Terdapat delapan kecerdasan yang dimiliki siswa di dalam dirinya meliputi kecerdasan verbal linguistik, visual spasial, logika matematika, musikal, kinestetik, intrapersonal, interpersonal dan naturalis (Gardner, 2011).
Karakteristik kecerdasan yang dimiliki setiap siswa menimbulkan adanya perbedaan kemampuan dalam bernalar, merumuskan, menjelaskan, dan menyelesaikan suatu permasalahan matematika tidak hanya dari konsep teoritis dan prosedural yang terdapat dalam buku paket maupun penjelasan dari guru melainkan dapat diselesaikan melalui kreativitas ide yang dimiliki setiap siswa.

Berdasarkan paparan tersebut, tujuan penelitian ini mendeskripsikan kemampuan literasi matematika siswa berdasarkan multiple intelligence dalam menyelesaikan soal matematika pada konten change and relationship dan space and shape.

\section{METODE PENELITIAN}

Metode yang digunakan dalam penelitian ini adalah deskriptif kualitatif. Pemilihan subjek dalam penelitian ini berdasarkan kecerdasan dominan yang dimiliki siswa kelas VIII SMP IT Ibnu Sina.

Instrumen penelitian berupa angket multiple intelligence, tes kemampuan literasi matematika pada konten change and relationship dan space and shape dan pedoman wawancara. Sebelum instrumen digunakan dilakukan validasi. Hasil validasi diperoleh untuk setiap instrumen berada dalam kategori sahih dengan rerata setiap instrumen 3,2 dan 3,4 sehingga instrumen layak digunakan.

Tahapan penelitian dimulai dengan memberikan angket multiple intelligence pada seluruh siswa kelas VIII yang berjumlah 22 orang untuk mengetahui kecerdasan dominan siswa. Hasil angket multiple intelligence diperoleh empat kecerdasan dominan yaitu kecerdasan intrapersonal, interpersonal, kinestetik dan logika 
matematika. Selanjutnya, dilakukan tes kemampuan literasi matematika pada empat orang siswa yang mewakili setiap kecerdasan dominan dan dilanjutkan dengan wawancara. Analisis data angket multiple intelligence dilakukan dengan menjumlahkan nilai setiap aspek kecerdasan. Nilai tertinggi setiap aspek menyatakan kecerdasan dominan siswa. Hasil tes kemampuan literasi matematika siswa dianalisis secara deskriptif berdasarkan kecerdasan dominan siswa. Analisis data dilakukan melalui 3 tahap yaitu reduksi data pada tahap ini dilakukan pemeriksaan hasil pekerjaan subjek yang sudah dikumpulkan, penyajian data yaitu proses pengumpulan informasi untuk ditarik kesimpulan dan penarikan kesimpulan pada tahap ini dilakukan proses perumusan dari hasil penelitian yang diperoleh. Pengujian krediabilitas data menggunakan triangulasi teknik. Kemampuan literasi matematika siswa dalam penelitian ini mengacu pada indikator PISA Mathematical Framework (OECD, 2016) yang diuraikan pada Tabel 1.

Tabel 1. Indikator kemampuan literasi matematika

\begin{tabular}{ll}
\hline \multicolumn{1}{c}{ Indikator } & \multicolumn{1}{c}{ Aspek yang dinilai } \\
\hline Kemampuan Komunikasi & $\begin{array}{l}\text { Dapat menerjemahkan pernyataan, pertanyaan, soal, } \\
\text { objek, gambar secara lengkap dan benar }\end{array}$ \\
Kemampuan Matematisasi & $\begin{array}{l}\text { Dapat mengidentifikasi variabel dan struktur } \\
\text { matematika yang mendasar dalam masalah dunia } \\
\text { nyata }\end{array}$ \\
$\begin{array}{l}\text { Kemampuan Memilih } \\
\text { Strategi }\end{array}$ & $\begin{array}{l}\text { Dapat merancang strategi dan merapkan fakta, } \\
\text { solusi }\end{array}$ \\
\hline
\end{tabular}

\section{HASIL DAN PEMBAHASAN}

Temuan dari penelitian ini diperoleh empat kecerdasan dominan siswa yang ditentukan berdasarkan nilai tertinggi setiap aspek kecerdasan yang diuraikan pada Tabel 2.

Tabel 2. Hasil angket multiple intelligence siswa kelas VIII SMP IT Ibnu Sina

\begin{tabular}{cc}
\hline Kecerdasan & $\begin{array}{c}\text { Nilai setiap } \\
\text { kecerdasan }\end{array}$ \\
\hline Verbal Linguistik & 261 \\
Musikal & 288 \\
Logika Matematika & 325 \\
Visual Spasial & 242 \\
Kinestetik & 330 \\
Intrapersonal & 367 \\
Interpersonal & 331 \\
Naturalis & 324 \\
\hline
\end{tabular}

Tabel 2 menunjukkan hasil dari delapan kecerdasan yang dipilih siswa kelas VIII SMP IT Ibnu Sina dimana kecerdasan intrapersonal, interpersonal, kinestetik dan logika matematika memiliki nilai yang lebih tinggi dibandingkan dengan kecerdasan yang lain walaupun perbedaan nilainya tidak begitu jauh.

Berdasarkan kecerdasan dominan, subjek yang digunakan dalam penelitian ini sebanyak empat siswa yang mewakili setiap kecerdasan. Subjek AAA mewakili kecerdasan intrapersonal, subjek RK mewakili kecerdasan interpersonal, subjek RDP mewakili kecerdasan kinestetik, dan subjek ASK mewakili kecerdasan logika matematika. 
DOI: https://doi.org/10.24127/ajpm.v10i1.3384

1. Kecerdasan Intrapersonal

Subjek dengan kecerdasan

intrapersonal yang diwakili oleh siswa
AAA menjawab soal seperti pada Gambar 1.

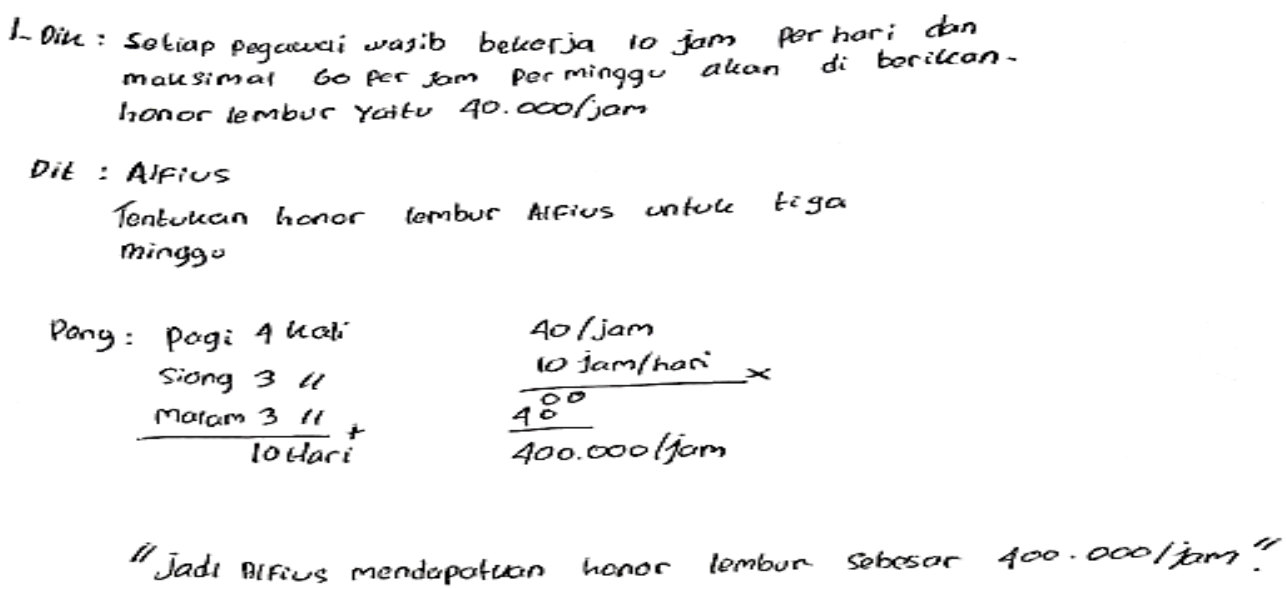

Gambar 1. Hasil pekerjaan subjek AAA dengan kecerdasan intrapersonal pada konten change and relationship

Berdasarkan Gambar 1, terlihat bahwa subjek dengan kecerdasan intrapersonal yang diwakili oleh siswa AAA telah memenuhi indikator komunikasi pada konten change and relationship dimana subjek telah mampu menuliskan informasi yang diperoleh dari soal walaupun tidak semua informasi dituliskan, mampu mengidentifikasi permasalahan yang terdapat pada soal secara tepat tetapi belum mampu menggambarkan situasi matematis secara tepat dan belum mampu memilih strategi yang digunakan dalam menyelesaikan masalah ini terlihat dari hasil pekerjaan subjek yang kurang tepat karena tidak menggunakan seluruh informasi pada soal yang terkait dengan aturan jam kerja karyawan. Hasil lain dari subjek AAA yang memiliki kecerdasan intrapersonal juga ditunjukkan seperti pada Gambar 2.

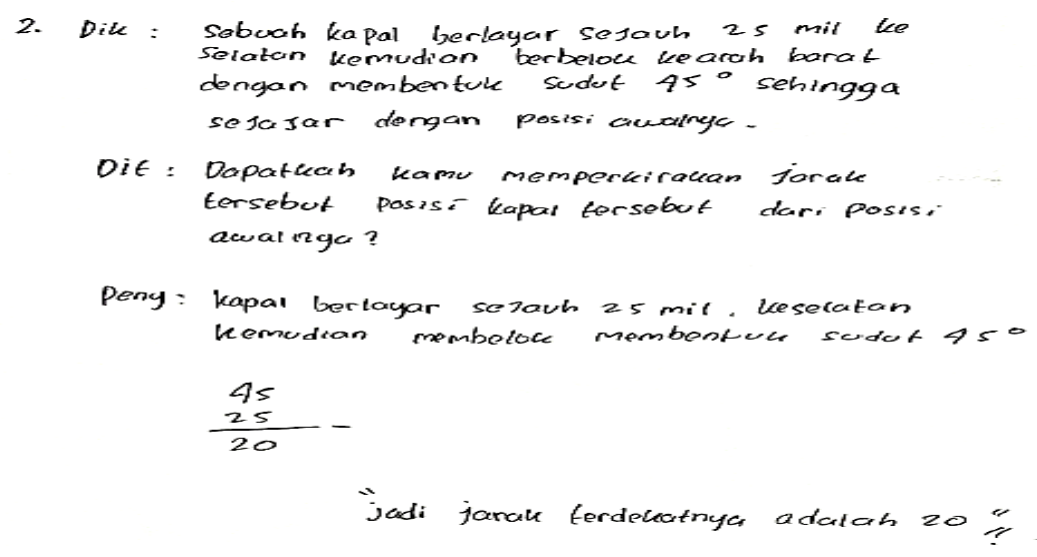

Gambar 2. Hasil pekerjaan siswa dengan kecerdasan intrapersonal pada konten space and shape 
DOI: https://doi.org/10.24127/ajpm.v10i1.3384

Berdasarkan Gambar 2, subjek dengan kecerdasan intrapersonal yang diwakili oleh siswa AAA telah memenuhi indikator komunikasi pada konten space and shape dimana subjek telah mampu menuliskan informasi yang diperoleh pada soal dan mampu mengidentifikasi permasalahan pada soal secara tepat tetapi belum memenuhi indikator kemampuan matematisasi dan memilih strategi, ini terlihat dari hasil pekerjaan subjek yang salah dalam proses penyelesaian dimana subjek melakukan operasi pengurangan antara sudut dan jarak, ini membuktikan subjek tidak memahami perbandingan panjang sisi segitiga pada materi phytagoras sehingga subjek kesulitan dalam menentukan jarak terdekat posisi kapal dari posisi awalnya.

2. Kecerdasan Interpersonal

\section{Ditanyakan: honor Alfius selama tiga mingga. Jawab: Pag; 4 kali Perming9a : $4 \times 5$ jam : 20}

Siang 3 kali Permingga : $3 \times 4$ jam: 12

malam 3 kali Perminggu: $3 \times 3$ jam: $\frac{9}{41 j a m}+$

Gambar 3. Hasil pekerjaan siswa dengan kecerdasan interpersonal pada konten change and relationship

Hasil dari jawaban siswa dengan kecerdasan interpersonal dapat dilihat pada Gambar 3. Berdasarkan Gambar 3, terlihat bahwa subjek dengan kecerdasan interpersonal yang diwakili oleh siswa RK pada konten change and relationship belum memenuhi indikator komunikasi hal ini terlihat dari pekerjaan subjek yang tidak menuliskan informasi yang diketahui pada soal, dan hanya menuliskan permasalahan pada soal. Subjek telah memenuhi indikator matematisasi, ini terlihat dari pekerjaan subjek yang mampu menggambarkan situasi matematis namun belum tepat dalam memilih strategi yang digunakan, terlihat dari adanya pengurangan jumlah jam kerja siang dan malam yang berkurang satu jam. Dalam persepsi subjek, setiap jam masuk harus melewati masa istirahat terlebih dahulu selama satu jam tetapi tidak demikian dalam penalaran logis, idealnya masa istirahat baru boleh dimanfaatkan jika karyawan tersebut telah bekerja pada waktu sebelumnya, sedangkan jika karyawan tersebut baru masuk kerja pada jam siang atau malam, karyawan tersebut harus langsung bekerja tanpa melewati waktu istirahat.

Hasil selanjutnya dari subjek RK dapat dilihat pada Gambar 4. Berdasarkan Gambar 4, Subjek dengan kecerdasan interpersonal yang diwakili oleh siswa RK pada konten space and shape belum memenuhi indikator kemampuan komunikasi ini terlihat dari hasil pekerjaan subjek yang tidak 
DOI: https://doi.org/10.24127/ajpm.v10i1.3384

menuliskan informasi yang terdapat pada soal, dan hanya menuliskan sebagian permasalahan pada soal. Lebih lanjut, subjek belum memenuhi indikator matematisasi dan kemampuan memilih strategi terlihat dari pekerjaan subjek yang masih bingung dalam menggambarkan arah dan tidak mengetahui langkah selanjutnya yang akan dilakukan, ini dikarenakan kurangnya pemahamn subjek pada materi phytagoras sehingga subjek kesulitan dalam menentukan jarak terdekat posisi kapal dari posisi awalnya.

\section{Ditanyakan : jarak Posisi kaPal \\ jawab: jarak dari posisiawal kapal 25 Mil dari arah selatan ke barat.}
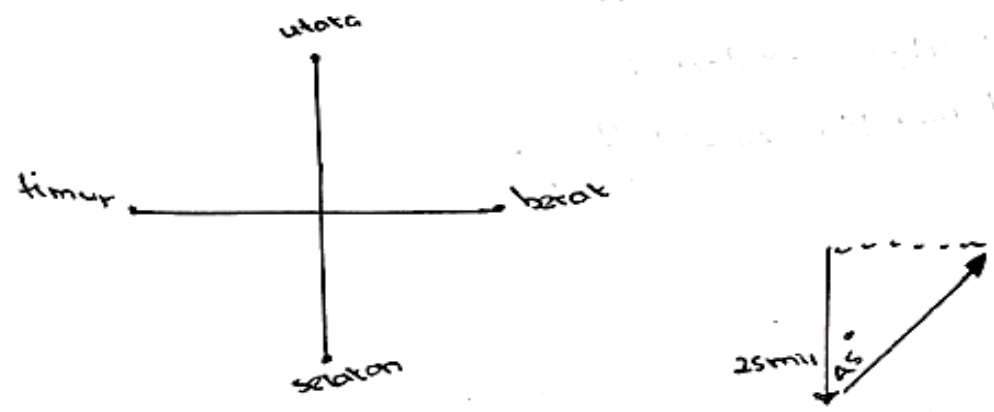

Gambar 4. Hasil pekerjaan siswa dengan kecerdasan interpersonal pada konten space and shape

3. Kecerdasan Kinestetik

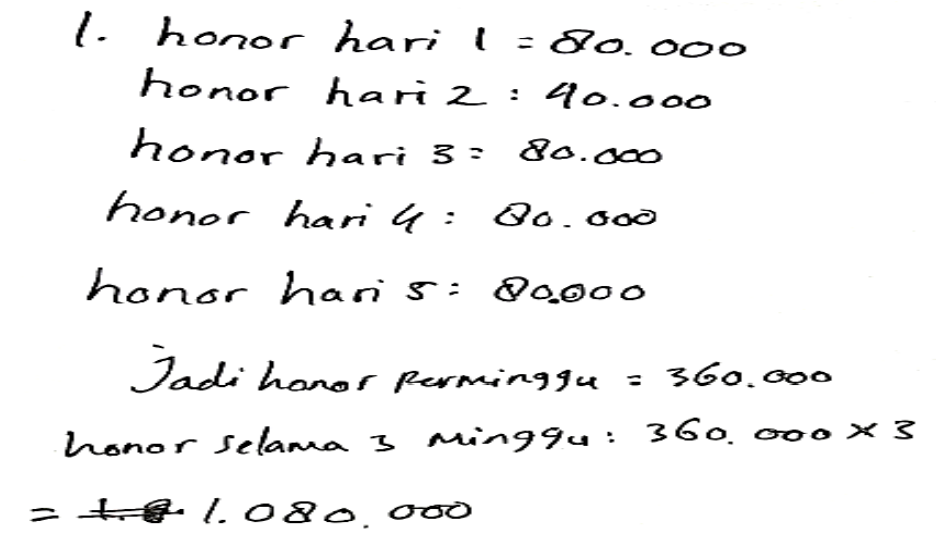

Gambar 5. Hasil pekerjaan siswa dengan kecerdasan kinestetik pada konten change and relationship

Hasil pekerjaan siswa yang memiliki kecerdasan kinestetik dapat dilihat pada Gambar 5. Berdasarkan Gambar 5, subjek dengan kecerdasan kinestetik yang diwakili oleh siswa RDP pada konten change and relationship belum memenuhi indikator kemampuan komunikasi, matematisasi 
dan kemampuan memilih strategi dalam menyelesaikan masalah. Hal ini terlihat dari pekerjaan subjek yang tidak menuliskan informasi yang benar pada soal, seperti apa yang diketahui dan ditanyakan, proses matematisasi dan strategi yang digunakan tidak tepat. Hal ini dikarenakan siswa tidak mengetahui langkah apa yang harus digunakan dalam menyelesaikan soal tersebut.

Hasil selanjutnya dari siswa RDP dapat dilihat pada Gambar 6 . Berdasarkan Gambar 6, Subjek dengan kecerdasan kinestetik yang diwakili oleh siswa RDP pada konten space and shape belum memenuhi indikator kemampuan komunikasi, matematisasi dan kemampuan memilih strategi dalam menyelesaiakan masalah, ini terlihat dari pekerjaan subjek yang menuliskan informasi pada soal hanya sebagian, namun tidak menuliskan apa yang diketahui dan ditanyakan pada soal, strategi yang digunakan tidak tepat, subjek kesulitan menentukan langkah yang harus digunakan dalam menentukan jarak terdekat posisi kapal dari posisi awalna, ini terlihat dari jawaban subjek yang salah dalam menafsirkan arah dari kapal tersebut. Ini membuktikan bahwa subjek tidak memahami materi phytagoras.

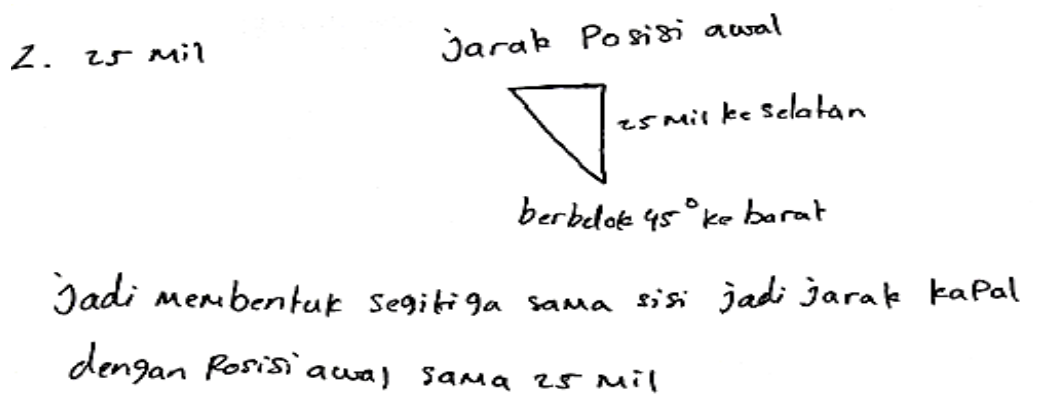

Gambar 6. Hasil pekerjaan siswa dengan kecerdasan kinestetik pada konten space and shape

4. Kecedasan Logika Matematika

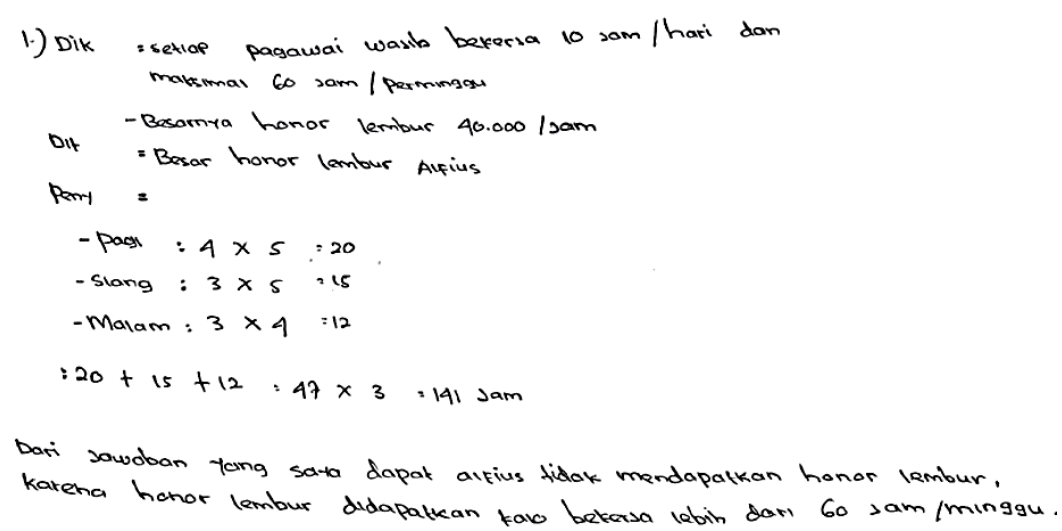

Gambar 7. Hasil pekerjaan siswa dengan kecerdasan logika matematika pada konten change and relationship 
Hasil dari pekerjaan siswa yang dalam hal ini adalah ASK selaku siswa yang memiliki kecerdasan logika matematika disajikan pada Gambar 7 . Berdasarkan Gamabr 7, subjek dengan kecerdasan logika matematika yang diwakili oleh siswa ASK pada konten change and relationship telah memenuhi indikator kemampuan komunikasi, matematisasi dan kemampuan memilih strategi dalam memecahkan masalah. Hal ini terlihat dari hasil pekerjaan subjek dimana subjek dapat menuliskan informasi yang diketahui dan ditanyakan pada soal serta mampu memilih strategi yang tepat. Hal ini sejalan dengan penelitian yang dilakukan Elisa, E. A (2017) menunjukkan bahwa siswa dengan kecerdasan logika matematika mampu mengidentifikasi informasi yang terdapat pada soal, mampu menerapkan strategi dari suatu permasalahan yang diberikan.

Selanjutnya, hasil pekerjaan ASK juga disajikan pada Gambar 8 .

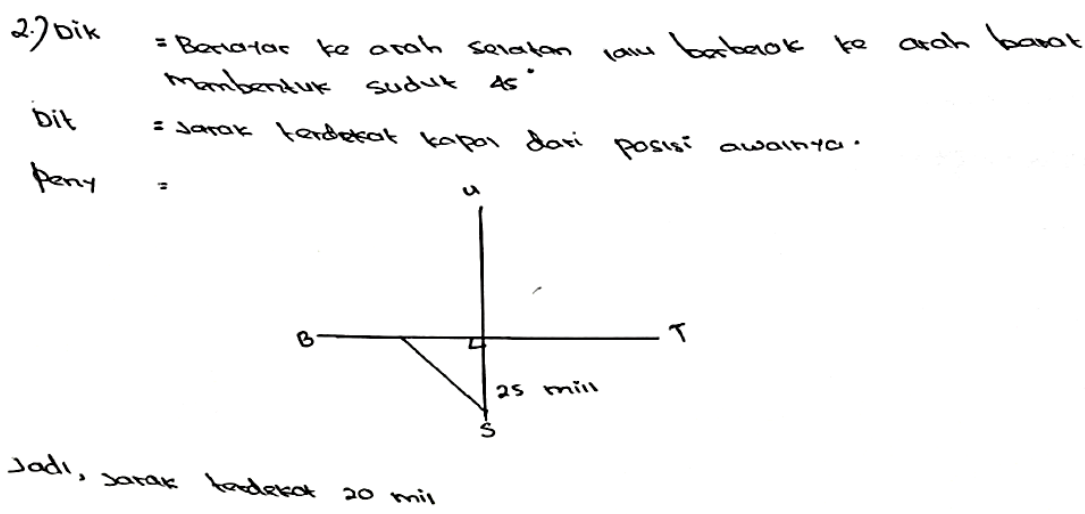

Gambar 8. Hasil pekerjaan siswa dengan kecerdasan logika matematika pada konten space and shape

Berdasarkan Gambar 8, subjek dengan kecerdasan logika matematika yang diwakili oleh siswa ASK pada konten space and shape telah memenuhi indikator kemampuan komunikasi ini terlihat dari hasil pekerjaan subjek yang telah mampu dalam menuliskan informasi yang diketahui dan ditanyakan pada soal tetapi belum memenuhi indikator matematisasi dan kemampuan memilih strategi, terlihat dari hasil pekerjaan subjek yang hanya menggambarkan arah kapal dan menyimpulkan secara langsung jawaban tanpa melalui proses ini dikarenakan subjek tidak memahami perbandingan panjang sisi segitiga pada materi phytagoras, sehingga subjek kesulitan dalam menentukan jarak terdekat posisi kapal dari posisi awalnya. Hal ini sejalan dengan penelitian yang dilakukan Fakhriyana, D.,Mardiyana.,\& Aryuna, D.R (2018) bahwa tidak semua siswa mampu menentukan strategi yang digunakan dalam menyelesaikan masalah walaupun siswa mampu dalam mengidentifikasi informasi yang relevan dari permasalahan yang diberikan. Namun, berbeda dengan penelitian sebelumnya yang dilakukan oleh Kurniawati, I., \& Kurniasari, I (2019) tentang kemampuan literasi matematis siswa dengan kecerdasan logis matematis pada konten space and shape, pada penelitian ini subjek dengan kecerdasaan logis matematis mampu menerjemahkan soal ke dalam bahasa matematika yaitu melalui proses 
pengukuran, penggunaan representasi simbol dan penggunaan representasi geometris serta subjek mampu merancang strategi untuk menentukan solusi dengan konsep matematika yang akan digunakan untuk menyelesaikan masalah.

\section{KESIMPULAN DAN SARAN}

Kemampuan literasi matematika subjek dengan kecerdasan intrapersonal dalam menyelesaikan soal matematika pada konten change and relationship dan space and shape hanya memenuhi indikator kemampuan komunikasi. Kemampuan literasi matematika subjek dengan kecerdasan interpersonal dalam menyelesaikan soal matematika pada konten change and relationship hanya memenuhi indikator matematisasi dan pada konten space and shape belum memenuhi indikator kemampuan komunikasi, matematisasi dan kemampuan memilih strategi. Kemampuan literasi matematika subjek dengan kecerdasan kinestetik dalam menyelesaikan soal matematika pada konten change and relationship dan space and shape belum memenuhi indikator kemampuan komunikasi, matematisasi dan kemampuan memilih strategi. Kemampuan literasi matematika subjek dengan kecerdasan logika matematika dalam menyelesaikan soal matematika pada konten change and relationship telah memenuhi indikator kemampuan komunikasi, matematisasi dan kemampuan memilih strategi tetapi belum memenuhi kemampuan matematisasi dan memilih strategi pada konten space and shape.

Diharapkan penelitian ini dapat menjadi acuan bagi guru dalam mengukur kemampuan literasi matematika siswa pada konten change and relationship dan space and shape, serta menjadi acuan dalam mengidentifikasi kecerdasan dominan yang dimiliki setiap siswa. Bagi peneliti lain, diharapkan penelitian ini dapat dijadikan sebagai acuan bagi penelitipeneliti selanjutnya yang mempunyai relevansi dalam variabel-variabelnya. Keterbatasan dan kekurangan dalam penelitian ini hendaknya dapat dijadikan pembelajaran untuk penelitian yang lebih baik.

\section{UCAPAN TERIMA KASIH}

Terima Kasih kepada pihak Universitas Musamus yang telah mendanai kegiatan penelitian Dosen Pemula DIPA Tahun 2020 dengan Nomor: 177.12/UN52.8/ LT/2020 Tanggal 04 September 2020.

\section{DAFTAR PUSTAKA}

Gench, M. \& Erbas. A. K. (2019). Secondary Mathematics

Teachers' Conceptions of Mathematical Literacy. IJEMST : International Journal of Education in Mathematics, Science and Technology, 7(3).

Sari, Rosalia Hera Novita. (2015). Literasi Matematika: Apa, Mengapa dan Bagaiman? Makalah disajikan dalam Seminar Nasional Matematika dan Pendidikan Matematika. Universitas Negeri Yogyakarta, ISBN 978-602- 73403-0-5.

OECD. 2013. PISA 2012 Assessment and Analytical Framework: Mathematics, Reading, Science, Problem Solving and Financial Literacy. Paris: OECD Publishing.

Stacey, Kaye. (2011). The PISA View Of Mathematical Literacy In Indonesia. J.M.E: Journal on Mathematics Education , 2(2), 95-126. 
OECD. (2019). PISA 2018 Assessment and Analytical Framework. OECD Report.

Haarh, J., Nielsen, T., Hansen, E, \& Jakobsen, S. (2005). Explaining Student Performance: Evidence from the International PISA, TIMSS and PIRLS Surveys. Danish Technological Institute.

Johar, Rahmah. 2012. Domain Soal PISA untuk Literasi Matematika. Jurnal Peluang, 1(1), ISSN: 2302-5158.

Aini, N. R, dkk. (2018). Analisis Berpikir Literasi Matematika Siswa Dalam Menyelesaikan Soal Matematika Pada Pokok Bahasan Pola Bilangan Berdasarkan Kecerdasan Majemuk. Kadikma: Jurnal Matematika dan Pendidikan Matematika, 9(2).

https://doi.org/10.19184/kdma.v9i2.996 4

Munfarikhatin, A \& Natsir, I. (2020). Analisis Kemampuan Literasi Matematika Siswa pada Konten Space and Shape. Histogram: Jurnal Pendidikan Matematika 4(1), 128-138.

Widodo, S.A.,Sunardi.,\& Diah, N. (2015). Identifikasi Kemampuan Literasi Matematika Siswa Kelas XIA-4 SMA Negeri 1 Ambulu. Artikel Ilmiah Mahasiswa, 1(1), $1-5$.

Astuti, N.K., Fahinu., \& Masuha, J. (2018). Analisis Kemampuan Literasi Matematika Siswa Kelas VIII SMP Swasta di Kota Kendari. JPPM: Jurnal Penelitian Pendidikan Matematika, 6(1), 99-112.

Syawahid, M.,\& Putrawangsa, S. (2017). Kemampuan Literasi Matematika Siswa SMP Ditinjau dari Gaya Belajar. Beta: Jurnal Tadris Matematika, 10(2), 222240.

http://dx.doi.org/10.20414/betajt m.v10i2.121

Gardner, H. (2011). Multipel Intelligence (Terjemahan). Jakarta: Daras Book.

OECD. (2016). PISA 2015 Results (volume I): excellence and equity in education. Paris: OECD Publishing.

Elisa, E.A. (2017). Kemampuan Literasi Matematika Siswa Kelas VIII dalam Menyelesaikan Soal PISA Konten Bilangan Ditinjau dari Kecerdasan Majemuk. MATHEdunesa: Jurnal Pendidikan Matematika, 1(6), 67-72

https://doi.org/10.21274/jtm.2018.1.1.18.

Fakhriyana, D.,Mardiyana.,\& Aryuna, D.R. (2018). Analisis Kemampuan Literasi Matematika dalam Memecahkan Masalah Model Programme For International Student Assesment (PISA) pada Konten Perubahan dan Hubungan Ditinjau dari Kecerdasan Logis Matematis Siswa Kelas IX SMP Muhammadiyah Program Khusus Surakarta. JPMM: Jurnal Pendidikan Matematika dan Matematika, 2(6), 421-434.

Kurniawati, I., \& Kurniasari, I. (2019). Literasi Matematika Siswa dalam Menyelesaikan Soal PISA pada Konten Space and Shape Ditinjau dari Kecerdasan Majemuk. MATHEdunesa: Jurnal Ilmiah Pendidikan Matematika, 8(2), 441-448. 